\title{
Analisis Algoritma K-Means dan K-Medoids Untuk Clustering Data Kinerja Karyawan Pada Perusahaan Perumahan Nasional
}

\author{
Akhmad Upi Fitriyadi $^{1}$; Ana Kurniawati ${ }^{2}$ \\ ${ }^{1,2}$ Universitas Gunadarma \\ 1 ahmaduvi99@mail.com
}

\begin{abstract}
ABSTRAK
Penilaian kinerja dilakukan untuk mengukur kinerja seorang karyawan terhadap pekerjaan yang dilakukan. Perusahaan Perumahan Nasional melakukan penilaian kinerja terhadap karyawan setiap 6 bulan sekali, yang melibatkan semua karyawan, baik karyawan tetap maupun karyawan kontrak. Tujuan dari penlitian ini adalah untuk melakukan analisis terhadap kinerja algoritma K-Means dan algoritma K-Medoids dalam melakukan proses clustering. Clustering akan dikelompokan menjadi 4 cluster yaitu: tingkat kinerja sangat baik, tingkat kinerja baik, tingkat kinerja cukup dan tingkat kinerja kurang baik. Proses clustering akan dilakukan mengunakan software rapidminer. Pengukuran performa algoritma dalam rapidminer dilakukan mengunakan metode Confusion Matrix dengan parameter accuracy, recall dan precision. Dari penelitian yang dilakukan diperoleh hasil algoritma K-Means mempunyai tingkat accuracy 56\%, presision 25\% dan recall $60 \%$, sedankan algoritma K-Medoids mempunyai tingkat akurasi $14 \%$, presision $25 \%$ dan recall $25 \%$. Dengan hasil tersebut dapat disimpulkan bahwa algoritma K-Means mempunyai performa lebih baik bila dibandingkan dengan algoritma K-Medoids, karena mempunyai tinngkat akurasi dan recell lebih tinggi bila dibandingkan dengan algoritma K-Medoids.
\end{abstract}

Kata kunci: Data Mining, Algoritma K-Means, Algoritma K-Medoids

\begin{abstract}
Performance appraisal must be carried out to measure the performance of an employee. Perumahan Nasional Company conduct employee performance appraisals every 6 months, that involves all employees, both permanent and contract employees. The purpose of this research is to analyze the performance of the K-Means algorithm and the K-Medoids algorithm in working on the clustering process. The clustering will be grouped into 4 clusters of performance level, that is: very good, good, adequate and poor. The Clustering process will be carried out using Rapidminer software. Measurement of algorithm performance in rapidminer is processed using the Confusion Matrix method with accuracy, recall and precision parameters. From the research results, the K-Means algorithm have an accuracy level of 56\%, Precision $25 \%$ and Recall $60 \%$, while the K-Medoids algorithm has an accuracy rate of $14 \%$, Precision $25 \%$ and Recall $25 \%$. The conclusion is that the K-Means algorithm has better performance when compared to the K-Medoids algorithm, because it has a higher level of accuracy and recall when compared to the K-Medoids algorithm.
\end{abstract}

Keywords: Data Mining, K-Means Algorithm, K-Medoids Algorithm 


\section{KILAT}

Vol. 10, No. 1, April 2021, P-ISSN 2089-1245, E-ISSN 2655-4925

DOI: https://doi.org/10.33322/kilat.v10i1.1174

\section{PENDAHULUAN}

Sumber daya manusia merupakan suatu faktor yang sangat penting dalam suatu organisasi atau perusahaan. Semakin banyak karyawan yang dimiliki oleh suatu perusahaan, akan semakin berat beban Divisi Sumber Daya Manusia (SDM) dalam menjalankan tugas untuk melakukan pengelolaan karyawan. Untuk mengukur kinerja karyawan terhadap perusahaan, Divisi SDM telah melakukan penilaian kinerja terhadap masing-masing karyawan setiap 6 bulan, namun hasil dari penilaian tersebut belum dilakukan pengelompokan sesuai dengan kelas-kelas tertentu.

Untuk mempermudah Divisi SDM, dalam melakukan monitoring terhadap hasil penilaian kinerja karyawan yang telah dilakukan, diperlukan suatu metode pengelompokan data untuk menelompokan data penilaian kinerja karyawan sesuai dengan tingkat kinerjanya. Salah satu metode pengelompokan data adalah clustering, clustering merupakan suatu metode pengelompokan data, dengan menggelompokkan data yang mempunyai kemiripan karakteristik antara data satu dengan data lainnya. Dari beberapa algorima yang ada dalam clustering, peneliti akan mengunakan algoritma K-Means dan K-Medoids sebagai algoritma yang akan dibandingkan dalam proses pengelompokan data kinerja karyawan.

Dalam melakukan perbandingan kinerja algoritma K-Means dan K-Medoids, peneliti akan mengunakan 3 parameter untuk melakukan pengukuran dari kinerja kedua algoritma, parameter yang digunakan adalah: Accuracy, Recall dan Precision. Dengan banyaknya parameter yang digunakan untuk melakukan pengukuran kinerja algoritma, diharapkan dapat memberikan hasil yang lebih akurat bila dibandinkan dengan hanya mengunakan 1 parameter. Dari hasil penelitian tersebut diharapkan dapat menentukan algoritma mana yang lebih baik, apabila digunakan dalam melakukan pengelompokan data kinerja karyawan.

Sebelum melakukan penelitian, peneliti melakukan review terhadap beberapa jurnal penelitian terdahulu yang dilakukan oleh peneliti-peneliti sebelumnya. Adapun jurnal-jurnal yang menjadi kajian pustaka dalam penelitian ini antara lain:

a. Pada Penelitian Nurhayati, dkk (2018) yang berjudul "Analysis of K-Means and $K$ Medoids's Performance Using Big Data Technology". Penelitian ini membandingkan algoritma K-Means dan K-Medoids dengan menguji data menggunakan aplikasi berbasis Java, Hadoop, dan Hive. Parameter yang digunakan dalam pengujian ini adalah akurasi, eksekusi. Dari pengujian tersebut diperoleh kesimpulan bahwa algoritma K-Medoids lebih baik bila dibandingkan dengan algoritma K-Means.

b. Pada Penelitian Agnis Nanda, dkk (2016) yang berjudul "Comparative Study between Parallel K-Means and Parallel K-Medoids using Message Passing Interface (MPI)". Penelitian ini menganalisis hasil dari kinerja waktu algoritma K-Means dan K-Medoids menggunakan High Performance Computing (HPC) dan untuk memparalelkan algoritma K-Means dan K-Medoids menggunakan pustaka Message Passing Interface (MPI). Hasil penelitian menunjukkan bahwa algoritma K-Means memberikan Jumlah Kuadrat Kesalahan (SSE) lebih kecil daripada K-Medoids sedangkan algoritma paralel yang menggunakan MPI memberikan komputasi yang lebih cepat.

c. Pada Penelitian Novita Lestari Anggreini, dkk (2020) yang berjudul "Komparasi Algoritma K-Means dan K-Medoids Untuk Menangani Strategi Promosi di Politeknik TEDC Bandung". Penelitian ini membahas mengenai perbandingan antara Algoritma KMeans dan Algoritma K-Medoids dalam klasterisasi, dan hasilnya dapat diusulkan menjadi pertimbangan untuk memutuskan dalam menangani strategi promosi di Politeknik TEDC Bandung dalam kegiatan Penerimaan Mahasiswa Baru. 
d. Pada Penelitian Ninda Nurul Rhamadani, dkk (2020) yang berjudul "Implementasi Algoritma K-Means dan K-Medoids Dalam Pengelompokan Nilai Ujian Nasional Tingkat $S M A$ ". Pada penelitian ini akan melakukan pengelompokan sekolah menjadi 3 kategori yaitu baik, sedang dan cukup untuk memudahkan peserta didik mendapatkan informasi kategori sekolah mereka dengan menerapkan algoritma K-Means dan K-Medoid. Hasil pengelompokan menggunakan algoritma k-means menghasilkan klaster baik sebanyak 14 anggota, klaster sedang 46 anggota dan klaster cukup 49 anggota. Lalu, pada algoritma kmedoids diperoleh hasil klaster baik 27 anggota, klaster sedang 43 anggota dan klaster cukup 39 anggota.

e. Pada Penelitian Rima Dias Ramadhani, dkk (2017) yang berjudul "Evaluasi K-Means dan K-Medoids pada Dataset Kecil". Pada penelitian ini akan membahas mengenai komparasi hasil evaluasi pada K-Means dan K-Medoids menggunakan dataset yang berukuran kecil yaitu dataset Iris dan Wine. Davies Bouldin Index digunakan pada penelitian ini untuk mengukur kesamaan dari ukuran klaster berdasarkan penyebaran data pada klaster dan ketidaksamaan ukuran klaster. Berdasarkan hasil eksperimen, K-Means menunjukkan hasil evaluasi yang lebih baik dibandingkan dengan K-Medoids dalam menangani dataset dengan ukuran kecil. Hal ini ditunjukkan dengan hasil evaluasi pada dataset Iris dengan menggunakan K-Means yaitu sebesar 0.662 dan pada dataset Wine menunjukkan hasil evaluasi sebesar 0.534 .

Dari penelitian-penelitain yang telah dilakukan oleh peneliti sebelumnya, sebagian besar peneliti hanya mengunakan 1 parameter yang digunakan dalam melakuakan pengukuran terhadap kinerja suatu algoritma. Dalam penelitian ini peneliti akan mengunakan 3 parameter untuk melakukan perandingan terhadap performa algoritma K-Means dan K-Medoids.

Berdasarkan permasalahan yang ada dalam Divisi SDM, tujuan dari penelitian ini adalah:

a. Melakukan analisa terhadap kinerja algoritma K-Means dan K-Medoids dalam melakukan proses clustering data.

b. Memberikan rekomendasi kepada divisi SDM hasil dari analisa kinerja kedua algoritma tersebut.

\subsection{Data Mining}

Istilah Data Mining digunakan untuk menjelaskan atau memaparkan penemuan ilmu pengetahuan di dalam database. Data mining merupakan serangkaian proses dalam pencarian pola, hubungan, penggalian nilai tambah dari data dan informasi yang berukuran besar berupa pengetahuan dengan tujuan menemukan hubungan dan menyederhanakan data agar diperoleh informasi yang dapat dipahami dan bermanfaat dengan bantuan ilmu statistik dan matematika [1, $3,12,17,19]$.

\subsection{Clustering}

Clustering adalah salah satu metode data mining yang bersifat tanpa arahan (unsupervised). Metode unsupervised yaitu metode yang diterapkan tanpa adanya latihan (training) dan guru (teacher) serta tidak memerlukan target output. Dalam data mining ada dua jenis metod clustering yang digunakan dalam pengelompokan data, yaitu hierarchical clustering dan non-hierarchical clustering (Santosa, 2007) [5, 6, 7, 9, 18]. 


\section{KILAT}

Vol. 10, No. 1, April 2021, P-ISSN 2089-1245, E-ISSN 2655-4925

DOI: https://doi.org/10.33322/kilat.v10i1.1174

\subsection{K-Means}

Algoritma K-Means merupakan teknik pengelompokan data dengan cara mempartisi data ke dalam beberapa cluster dengan menetapkan sejumlah objek data terdekatnya $[1,4,15,16]$.

Berikut ini langkah-langkah clustering yang terdapat pada algoritma K-Means adalah: 1) Tentukan $\mathrm{k}$ sebagai jumlah cluster yang dibentuk, 2) Tentukan $\mathrm{k}$ centroid (titik pusat cluster) awal secara random, 3) Hitung jarak setiap objek ke masing-masing centroid dari masing-masing cluster, 4) Alokasikan masing-masing objek ke dalam centroid yang paling dekat, 5) Lakukan iterasi, kemudian tentukan posisi centroid baru dengan menggunakan persamaan, 6) Ulangi langkah 3 jika posisi centroid baru tidak sama.

\subsection{K-Medoids}

Algoritma K-Medoids atau Partitioning Around Medoids (PAM) adalah algoritma clustering yang mirip dengan K-Means. Perbedaan dari kedua algoritma ini yaitu algoritma K-Medoids atau PAM menggunakan objek sebagai perwakilan (medoid) sebagai pusat cluster untuk setiap cluster $[8,10,11]$.

Langkah-langkah algoritma K-Medoids adalah: 1) Inisialisasi pusat clustersebanyak $\mathrm{k}($ jumlah cluster), 2) Alokasikan setiap data (objek) ke clusterterdekat menggunakan persamaan ukuran jarak Euclidian Distance, 3) Pilih secara acak objek pada masing-masing cluster sebagai kandidat medoid baru, 4) Hitung jarak setiap objek yang berada pada masing-masing cluster dengan kandidat medoid baru, 5) Hitung total simpangan (S) dengan menghitung nilai total distance baru-total distance lama, 6) Ulangi langkah 3 sampai 5 hingga tidak terjadi perubahan medoid, sehingga didapatkan cluster beserta anggota cluste rmasing-masing.

\subsection{Rapidminer}

Rapidminer merupakan perangakat lunak yang bersifat terbuka (open source) yang dibuat oleh Dr. Markus Hofmann dari Institute of Technologi Blanchardstown dan Ralf Klinkenberg dari rapid-i.com. Rapidminer adalah sebuah solusi untuk melakukan analisis terhadap data mining, text mining dan analisis prediksi. Rapidminer menggunakan berbagai teknik deskriptif dan prediksi dalam memberikan wawasan kepada pengguna sehingga dapat membuat keputusan yang paling baik. Rapidminer memiliki kurang lebih 500 operator data mining, termasuk operator untuk input, output, data preprocessing dan visualisasi. Rapidminer merupakan software yang berdiri sendiri untuk analisis data dan sebagai mesin data mining yang dapat diintegrasikan pada produknya sendiri. Rapidminer ditulis dengan munggunakan bahasa java sehingga dapat bekerja di semua sistem operasi $[2,13,14$,$] .$

\subsection{Confusion matrix}

Confusion Matrix merepresentasikan prediksi dan kondisi sebenarnya (aktual) dari data yang dihasilkan oleh algoritma machine learning. Berdasarkan Confusion Matrix, bisa ditentukan parameter yang digunakan untuk menegevaluasi suatu algoritma dalam suatu machine learning (rapidminer). Dalam penelitian ini parameter yang akan digunakan untuk mengukur performance algoritma dalam machine learning (rapidminer) adalah Accuracy, Precission, Recall [13].

\section{METODOLOGI PENELITIAN}

Metode penelitian yang digunakan pada penelitian ini adalah metode analisis deskriptif dengan pendekatan kuantitatif, artinya penelitian ini menekankan analisa pada data-data kinerja karyawan yang terdapat di Divisi SDM sebagai data yang akan digunakan dalam penelitian. Dalam 
melakuakan penelitain, akan dilakukan ujicoba pemrosesan data sebanyak 1 kali dengan mengunakan data sampel 20 data kinerja karyawan yang diambil secara acak.

\subsection{Observasi}

Observasi dilakukan dengan cara mendapatkan informasi secara langsung, terkait hal-hal yang berhubungan dengan penilaian kinerja. Dalam melakukan observasi peneliti menanyakan secara lansung kepada karyawan Divisi SDM, yang bertugas melakukan penilaian kinerja. Informasi yang diperoleh peneliti selama melakukan observasi adalah: 1) Informasi tentang jumlah karyawan, bahwa Perusahaan Perumahan Nasional mempunyai jumlah karyawan sebanyak 1520 karyawan , 2) Pelaksanaan penilaian kinerja karyawan dilakukan per semester, semester 1 dilakukan pada bulan Januari-Juni dan semester 2 bulan Juli-Desember, 3) Informasi tentang cara pelaksanaan penilaian kinerja, bahwa penilaian kinerja di isi oleh masing-masing karyawan, dan akan dinilai oleh atasan, 4) Dalam pelaksanaan penilaian kinerja karyawan ada banyak parameterparameter yang berpenaruh terhadap nilai penilaian kinerja, 5) Untuk melakukan perhitungan penilaian kinerja, Perusahaan mempunyai formula kusus, 6) Penilaian kinerja digunakan untuk menukur tinkat kinerja karyawan, untuk karyawan yang mempunyai nilai kinerja rendah akan diberikan pelatihan kusus, untuk meningkatkan kinerja karyawan tersebut, 7) Hasil dari penilaian kinerja belum dilakukan penelompokan secara kusus.

\subsection{Pengumpulan Data}

Penumpulan data dilakukan untuk mendapatkan data-data yang digunakan dalam penelitian. Dalam melakukan pengumpulan data, peneliti meminta data secara langsung kepada karyawan Divisi SDM yang bertugas melakukan penilaian kinerja. Data yang diperoleh selama melakukan pengumpulan data adalah berupa data excel, yang berisi data penilaian kinerja cecara detail.

Gambar 1 merupakan contoh data penilaian kinerja yang diperoleh penulis salama melakukan pengumpulan data. Dalam data tersebut menunjukan detail data penilaian kenerja dalam setiap parameter yang digunakan dalam melakukan pengukuran kinerja karyawan.

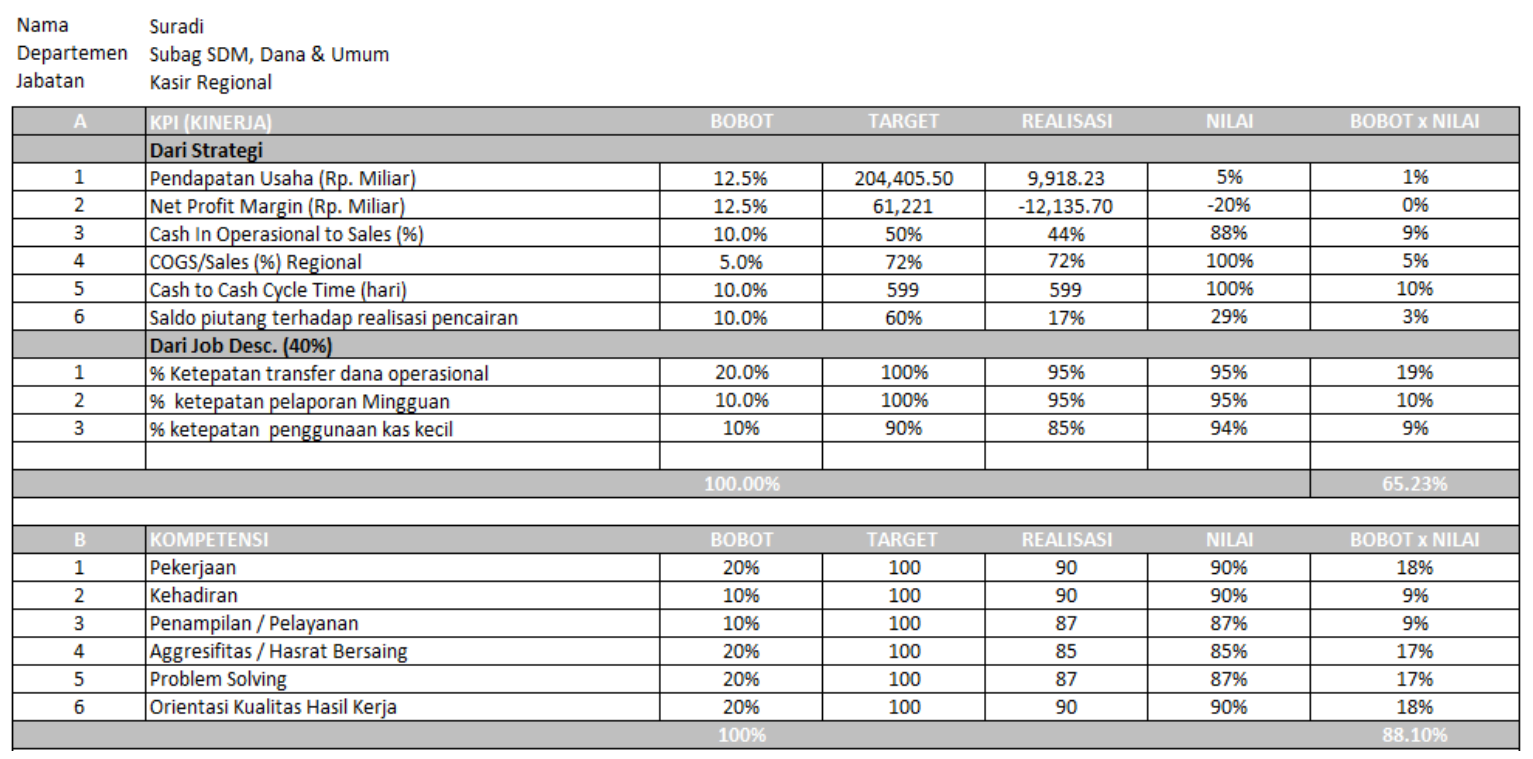

Gambar 1. Data Penilaian Kinerja Karyawan 


\section{KILAT}

Vol. 10, No. 1, April 2021, P-ISSN 2089-1245, E-ISSN 2655-4925

DOI: https://doi.org/10.33322/kilat.v10i1.1174

\subsection{Transformasi Data}

Transformasi data dilakukan untuk menyesuaikan format data yang dapat diproses oleh software Rapidminer, karena rapidmier mempunyai formas kusus agar data dapat di proses.

Tabel 1 Menunjukan format data excel yang digunakan peneliti untuk memasukan data kinerja karyawan kedalam software rapidminer. Dalam tabel tersebut menunjukan data kinerja karyawan yang telah dilakukan transformasi data dan siap untuk dilakukan pemrosesan data.

Tabel 1. Data Penilaian Kinerja Hasil Transformasi

\begin{tabular}{|l|c|c|c|c|c|c|c|c|}
\hline \multirow{2}{*}{ No } & \multicolumn{2}{|c|}{ Kinerja } & \multicolumn{5}{c|}{ Kompetensi } \\
\cline { 2 - 9 } & Strategi & Job Desc & Pekerjaan & Kehadiran & Penampilan & Aggresifitas & Problem Solving & Hasil Kerja \\
\hline k1 & 29 & 39 & 19 & 10 & 10 & 19 & 18 & 18 \\
\hline k2 & 27 & 40 & 18 & 9 & 9 & 17 & 18 & 18 \\
\hline k3 & 29 & 39 & 18 & 9 & 9 & 18 & 18 & 18 \\
\hline k4 & 29 & 38 & 20 & 10 & 9 & 20 & 19 & 19 \\
\hline k5 & 23 & 40 & 18 & 9 & 9 & 19 & 19 & 19 \\
\hline k6 & 23 & 36 & 18 & 10 & 9 & 18 & 18 & 18 \\
\hline $\mathrm{k} 7$ & 27 & 40 & 19 & 9 & 9 & 18 & 18 & 19 \\
\hline $\mathrm{k} 8$ & 27 & 40 & 19 & 9 & 9 & 18 & 18 & 19 \\
\hline $\mathrm{k} 9$ & 27 & 37 & 19 & 10 & 10 & 19 & 19 & 19 \\
\hline $\mathrm{k} 10$ & 27 & 40 & 19 & 9 & 9 & 18 & 18 & 19 \\
\hline $\mathrm{k} 11$ & 37 & 35 & 18 & 9 & 9 & 17 & 17 & 17 \\
\hline $\mathrm{k} 12$ & 26 & 37 & 19 & 9 & 9 & 19 & 18 & 19 \\
\hline $\mathrm{k} 13$ & 26 & 36 & 18 & 9 & 9 & 18 & 17 & 18 \\
\hline $\mathrm{k} 14$ & 26 & 34 & 17 & 9 & 9 & 17 & 16 & 17 \\
\hline $\mathrm{k} 15$ & 29 & 34 & 18 & 9 & 9 & 18 & 17 & 18 \\
\hline $\mathrm{k} 16$ & 26 & 34 & 18 & 9 & 9 & 17 & 17 & 18 \\
\hline $\mathrm{k} 17$ & 26 & 36 & 18 & 9 & 9 & 18 & 17 & 18 \\
\hline $\mathrm{k} 18$ & 26 & 36 & 17 & 9 & 9 & 16 & 17 & 17 \\
\hline $\mathrm{k} 19$ & 31 & 35 & 18 & 9 & 9 & 17 & 17 & 18 \\
\hline $\mathrm{k} 20$ & 22 & 39 & 19 & 10 & 10 & 19 & 19 & 19 \\
\hline
\end{tabular}

Data yang akan digunakan dalam penelitian ini adalah data penilaian kinerja karyawan semester 2 tahun 2019. Sedangkan data sampel yang aan digunakann berjumlah 20 data sampel yang telah diambil secara acak. Dalam proses penilaian kinerja ada beberapa parameter yang akan digunakan selama proses penilaian kinrja, parameter tersebut adalah strategi, job desc, pekerjaan, kehadiran, penampilan, aggresifitas, problem solving dan hasil kerja.

\section{PENGUJIAN DAN HASIL}

Penelitian ini akan melakukan perbandinan terhadap kinerja aloritma K-Means dan algoritma K-Medoids, dimana algoritma yang lebih baik akan direkomendasikan peneliti kepada perusahaan untuk dijadikan sebagai rujukan dalam melakukan penelompokan data.

\section{a. Pengujian Mengunakan Rapdminer}

Dalam melakukan pengujian menunakan rapid miner, maka peneliti akan memasukan data dalam format excel, untuk selanjutnya dilakukan pemrosesan data. Penujian ini dilakukan dua kali yaitu denan algoritma K-Means dan algoritma K-Medoids.

Tahapan proses pengolahan data menunakan rapidminer adalah:

1. Desain Input Proses

Sebelum melakukan pengolahan data mengunakan rapidminer tahap pertama yang dilakukan adalah membuat desain input proses. Desain input proses ini terdiri dari 3 operator yaitu, operator Read excel, algoritma clustering dan performance. Gambar 2 menunjukan desain proses yang akan dijalankan dalam rapidminer. 


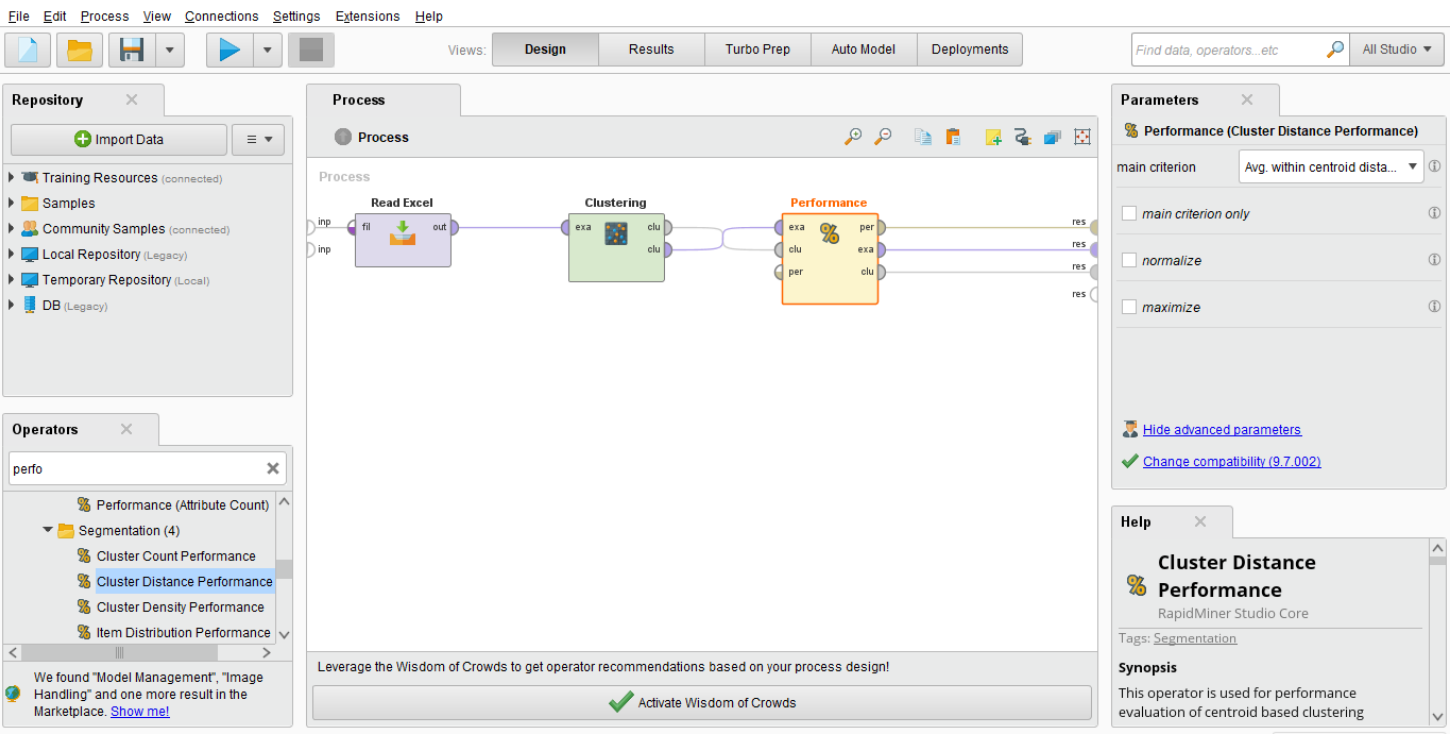

Gambar 2. Desain Input Proses

2. Proses Pengambilan Data

Proses pengambilann data merupakan tahapan yang dilakukan untuk memasukan data excel yang telah disiapkan, kedalam software rapidminer. Pada tahap ini data akan dimasukan ke dalam rapidminer, untuk selanjutnya dilakukan pemrosesan. Gambar 3 merupakan proses import data excel ke dalam software rapidminer.

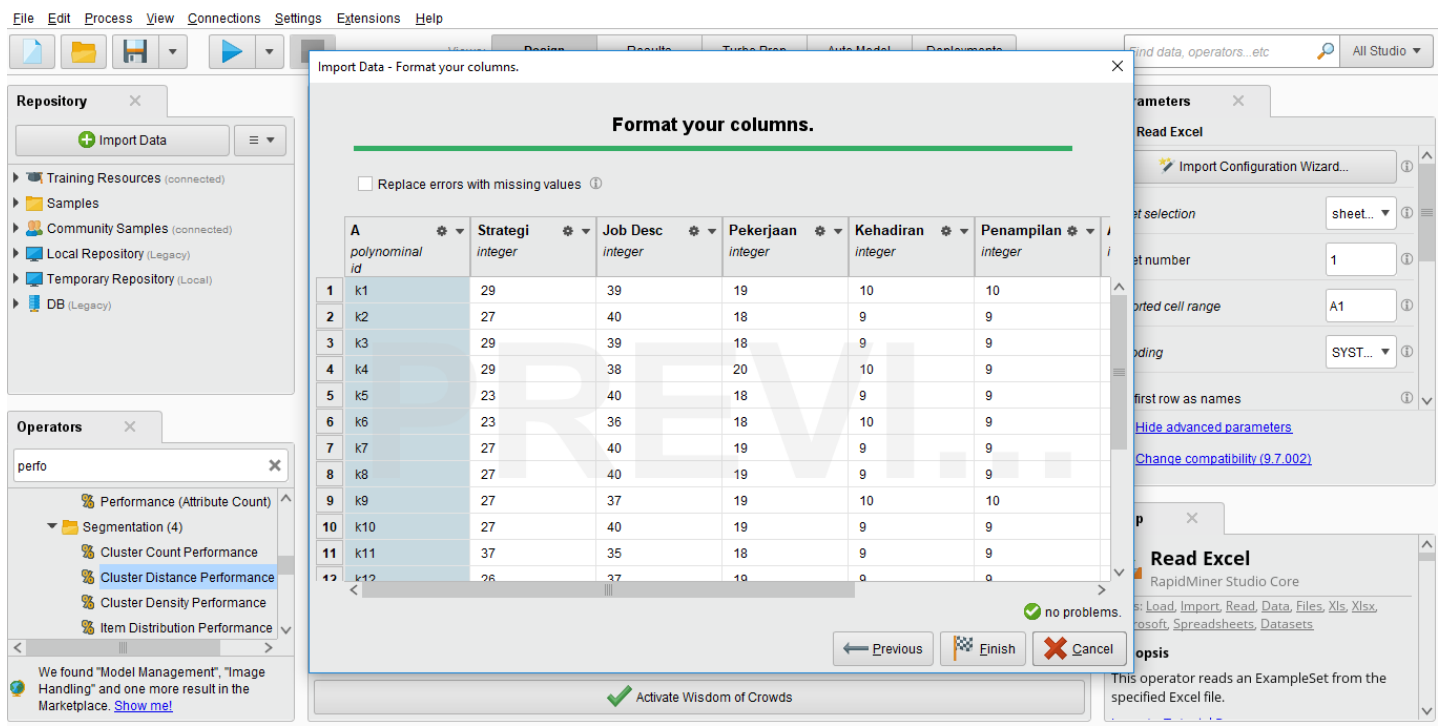

Gambar 3. Proses Import Data Excel

\section{Hasil Clustering}

Output pertama yang dihasilkan setelah tahap proses mengunakan rapidminer adalah output tentang jumlah data dalam stiap cluster. Output ini memberikan informasi secara global tentang jumlah data dalam setiap cluster. Gambar 4 merupakan output data clustering per cluster secara global. Pada Gambar 4 kita bisa memperoleh informasi tentang jumlah data kinerja karyawan per cluster. 


\section{KILAT}

Vol. 10, No. 1, April 2021, P-ISSN 2089-1245, E-ISSN 2655-4925

DOI: https://doi.org/10.33322/kilat.v10i1.1174

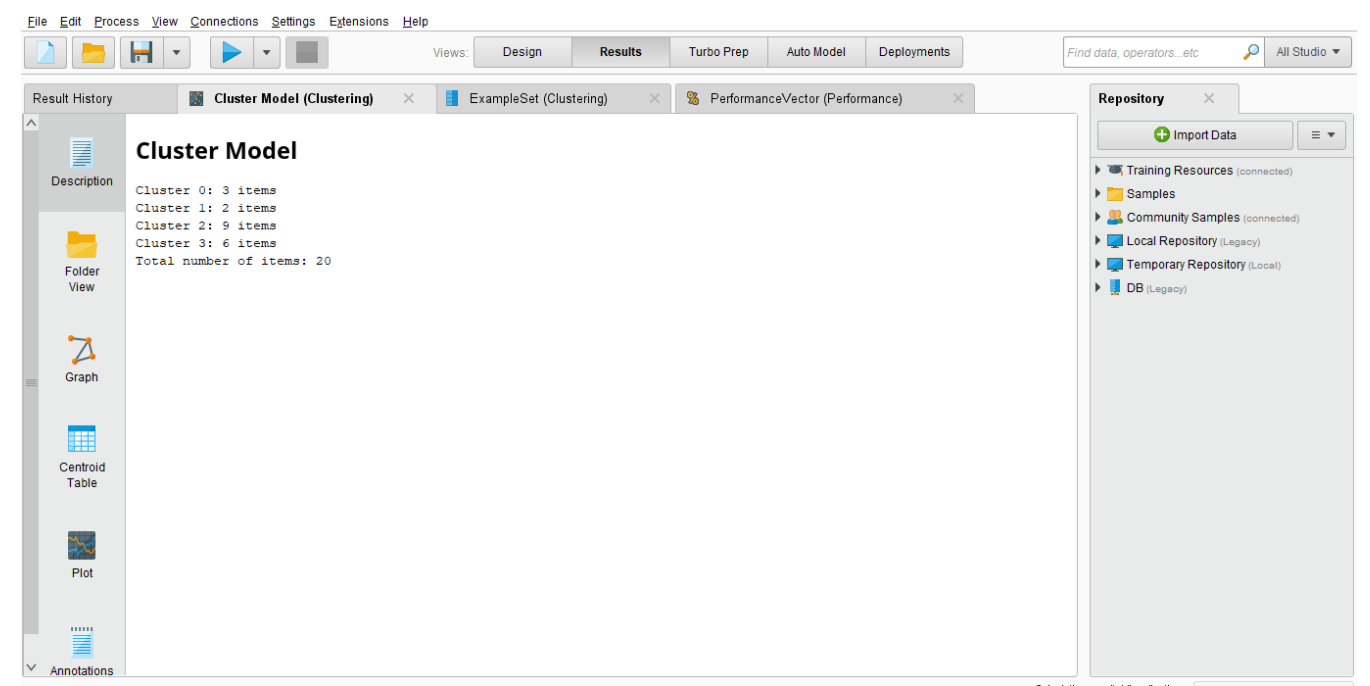

4. Hasil Tabel Centroid

\section{Gambar 4. Hasil Clustering}

Output ini memberikan informasi tentang titik centroid dalam setiap cluster, dari hasil proses data yang telah dilakukan. Gabar 5 menunjukan data centroid baru yang terbentuk setelah proses clustering data menggunakan rapidminer.

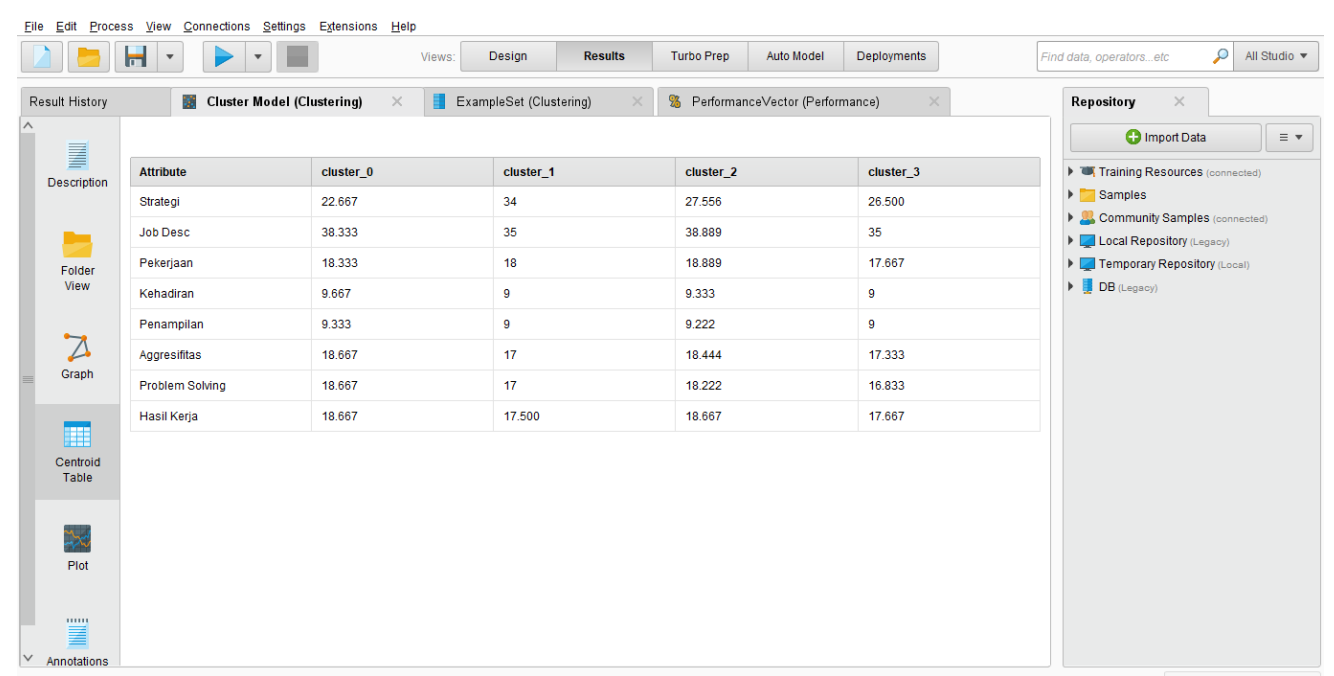

Gambar 5. Hasil Tabel Centroid

\section{b. Hasil Pengujian}

Dari hasil pengujian kedua algoritma yang telah dilakukan diperoleh hasil pengelompokan data kinerja karyawan dalam setiap cluster. Tabel 2 memberikan informasi mengenai jumlah data dalam setiap cluster dari kedua algoritma. Dari hasil pengujian kedua algoritma menunjukan, meskipun data kinerja karyawan yang diproses sama, ternyata setalah dilakukan pengelompokan menggunakan algoritma berbeda, ternyata memberikan hasil cluster yang berbeda pula.

Tabel 2. Tabel Hasil Pengujian

\begin{tabular}{|c|c|c|c|c|c|}
\hline No & Algoritma & Cluster 0 & Cluster 1 & Cluster 2 & Cluster 3 \\
\hline 1 & Algoritma K-Means & 3 & 2 & 9 & 6 \\
\hline 2 & Algoritma K-Medoids & 9 & 11 & 0 & 0 \\
\hline
\end{tabular}




\section{c. Perbandingan Kinerja Algoritma}

Dalam melakukan evaluasi terhadap performance algoritma machine learning (khususnya rapidminer), kita menggunakan acuan Confusion Matrix. Confusion Matrix merepresentasikan prediksi dan kondisi sebenarnya(aktual) dari data yang dihasilkan oleh algoritma machine learning. Berdasarkan Confusion Matrix, bisa ditentukan parameter yang digunakan untuk menegevaluasi suatu aloritma dalam suatu machine learning (rapidminer) . Dalam penelitian ini parameter yang akan diunakan untuk mengukur performance algoritma dalam machine learning (rapidminer) adalah Accuracy, Precission, Recall.

Dari hasil pengujian yang telah dilakukan, dapat dilakukan perhitungan Confusion Matrix dari kedua algoritma tersebut adalah:

1. Algoritma K-Means

Tabel 3 merupakan tabel matrix Confusio Matrik dengan mengunakan algoritma K-Means.

Tabel 3. Tabel Confusion Matrix K-Means

\begin{tabular}{|c|c|c|c|}
\hline \multicolumn{2}{|c|}{ Analisa Dengan } & \multicolumn{2}{c|}{ K-Means } \\
\cline { 3 - 4 } \multicolumn{2}{|c|}{} & Cluster 0 & Cluster 1 \\
\hline \multirow{2}{*}{ K-Medoids } & Cluster 0 & 3 & 9 \\
\cline { 2 - 4 } & Cluster 1 & 2 & 11 \\
\hline
\end{tabular}

2. Algoritma K-Medoids

Tabel 3 merupakan tabel matrix Confusio Matrik dengan mengunakan algoritma K-Medoids.

Tabel 4. Tabel Confusion Matrix K-Medoids

\begin{tabular}{|l|c|c|c|}
\hline \multicolumn{2}{|c|}{ Analisa Dengan } & \multicolumn{2}{c|}{ K-Means } \\
\cline { 3 - 4 } \multicolumn{2}{|c|}{} & Cluster 0 & Cluster 3 \\
\hline \multirow{2}{*}{ K-Medoids } & Cluster 0 & 3 & 9 \\
\cline { 2 - 4 } & Cluster 3 & 9 & 0 \\
\hline
\end{tabular}

\section{i. Accuracy}

Untuk mengetahui tingkat akurasi suatu algoritma dalam melakukan pemrosesan data, maka harus dilakukan perhitungan dengan persamaan seagai berikut:

Accuracy $=((\mathrm{TP}+\mathrm{TN}) /(\mathrm{TP}+\mathrm{FP}+\mathrm{FN}+\mathrm{TN})) \times 100 \%$

(1)

Dari pengujian kinerja karyawan yang telah dilakukan, maka peneliti akan melakukan perhitungan akurasi dari hasil pemrosesan data tersebut. Berikut merupakan detail dari perhitungan accuracy dengan mengunakan confucion matrix:

1. Algoritma K-Means

$$
\begin{aligned}
\text { Accuracy } & =((3+11) /(3+9+2+11)) \times 100 \% \\
& =(14 / 25) \times 100 \% \\
& =0.56 \times 100 \% \\
& =56 \%
\end{aligned}
$$

2. Algortima K-Medoids

$$
\begin{aligned}
\text { Accuracy } & =((3+0) /(3+9+9+0)) \times 100 \% \\
& =(3 / 21) \times 100 \% \\
& =0.14 \times 100 \% \\
& =14 \%
\end{aligned}
$$




\section{KILAT}

Vol. 10, No. 1, April 2021, P-ISSN 2089-1245, E-ISSN 2655-4925

DOI: https://doi.org/10.33322/kilat.v10i1.1174

Dengan menggunakan rumus confusion matrix diperoleh, nilai accuracy dari kedua algoritma. Algoritma K-Means mempunyai nilai accuracy 56\% sedangkan algoritma K-Medoids mempunyai nilai accuracy $14 \%$.

\section{ii. Precission}

Merupakan rasio prediksi benar positif dibandingkan dengan keseluruhan hasil yang diprediksi positf. Berikut merupakan detail perhitungan precission dari kedua algoritma.

Precission $=(\mathrm{TP}) /(\mathrm{TP}+\mathrm{FP})$

(2)

1. Algoritma K-Means

$$
\begin{aligned}
\text { Precission } & =(3 /(3+9)) \times 100 \% \\
& =(3 / 12) \times 100 \% \\
& =0.25 \times 100 \% \\
& =25 \%
\end{aligned}
$$

2. Algortima K-Medoids

$$
\begin{aligned}
\text { Precission } & =(3 /(3+9)) \times 100 \% \\
& =(3 / 12) \times 100 \% \\
& =0.25 \times 100 \% \\
& =25 \%
\end{aligned}
$$

Dengan menggunakan rumus confusion matrix diperoleh, nilai precission dari kedua algoritma. Algoritma K-Means mempunyai nilai precission 25\% sedangkan algoritma K-Medoids mempunyai nilai accuracy $25 \%$.

\section{iii. Recall}

Merupakan rasio prediksi benar positif dibandingkan dengan keseluruhan data yang benar positif. Berikut merupakan hasil perhitungan denan mengunakan recall.

$$
\text { Recall }=(\mathrm{TP}) /(\mathrm{TP}+\mathrm{FN})
$$

(3)

1. Algoritma K-Means

$$
\begin{aligned}
\text { Recall } & =(3 /(3+2)) \times 100 \% \\
& =(3 / 5) \times 100 \% \\
& =0.6 \times 100 \% \\
& =60 \%
\end{aligned}
$$

2. Alortima K-Medoids

$$
\begin{aligned}
\text { Recall } & =(3 /(3+9)) \times 100 \% \\
& =(3 / 12) \times 100 \% \\
& =0.25 \times 100 \% \\
& =25 \%
\end{aligned}
$$

Dengan menggunakan rumus confusion matrix diperoleh, nilai recall dari kedua algoritma. Algoritma K-Means mempunyai nilai recall 60\% sedangkan algoritma K-Medoids mempunyai nilai accuracy $25 \%$.

\section{KESIMPULAN DAN SARAN}

\section{a. Kesimpulan}

Dari hasil perhitungan yang telah dilakukan dengan menggunakan metode Confusion Matrix, diperoleh hasil bahwa: Dengan menggunakan parameter accuracy algoritma K-Means mempunyai 
nilai 56\% sedangkan K-Medoids mempunyai nilai 14\%, Dengan menggunakan parameter recall algoritma K-Means mempunyai nilai $60 \%$ sedangkan K-Medoids mempunyai nilai 25\%, Dengan menggunakan parameter precission algoritma K-Means mempunyai nilai $25 \%$ sedangkan KMedoids mempunyai nilai $25 \%$. Hasil dari perhitungan yang dilakukan dapat ditarik kesimpulan bahwa algoritma K- Means lebih baik bila dibandingkan algoritma K-Medoids, karena mempunyai tinngkat akurasi dan recell lebih tinggi bila dibandingkan dengan algoritma K-Medoids. Dari hadil tersebut peneliti akan merekomendasikan algoritma K-Means sebagai algoritma yang akan digunakan dalam melakukan clustering data kinerja karyawan kepada Divisi SDM.

\section{b. Saran}

Penelitian ini baru melakukan clustering terhadap karyawan di level staf, sementara di perusahaan Perumahan Nasional masih banyak lagi karyawan dengan jabatan-jabatan yang lain. Untuk dapat melihat clustering data secara global perlu dilakukan penelitian mengenai clustering data kinerja karyawan secara keseluruhan.

Algoritma yang digunakan untuk melakukan clustering data sangat banyak, oleh karena itu perlu dilakukan pembandingan clustering karyawan dengan algoritma yang lain, untuk mengetahui performance dari algoritma tersebut. Misalnya algoritma X-Means, Fuzzy C-Means dan Mixture Modelling. Selain menggunakan algoritma yang berbeda, penelitian juga bisa dilakukan menggunakan menggunakan machine learning yang lain misalnya WEKA, Rattle, Orange dan KNIME.

\section{DAFTAR PUSTAKA}

[1] I. H. Rifa, H. Pratiwi, and R. Respatiwulan, "Clustering of Earthquake Risk in Indonesia Using K-Medoids and K-Means Algorithms,” Media Stat., vol. 13, no. 2, pp. 194-205, 2020, doi: 10.14710/medstat.13.2.194-205.

[2] F. Farahdinna, I. Nurdiansyah, A. Suryani, and A. Wibowo, "Perbandingan Algoritma KMeans Dan K-Medoids Dalam Klasterisasi Produk Asuransi Perusahaan Nasional," J. Ilm. FIFO, vol. 11, no. 2, p. 208, 2019, doi: 10.22441/fifo.2019.v11i2.010.

[3] Y. H. Susanti and E. Widodo, "Perbandingan K-Means dan K-Medoids Clustering terhadap Kelayakan Puskesmas di DIY Tahun 2015," vol. 1, no. 1, pp. 116-122, 2017.

[4] Mediana, E. D. Madyatmadja, and E. Miranda, "Application of K-Means and K-Medoids Clustering Pada Data Internet Banking Di Bank Xyz,” pp. 349-356, 2018.

[5] P. Kumar and D. Sirohi, "Comparative analysis of FCM and HCM algorithm on Iris data set," Int. J. Comput. Appl., vol. 5, no. 2, pp. 33-37, 2010, doi: 10.5120/888-1261.

[6] C. K. Raj, "Comparison of k-means, k-medoids, DBSCAN algorithms using DNA microarray dataset," Int. J. Comput. Appl. Math., vol. 12, no. 1, pp. 344-355, 2017.

[7] W. AS, M. K. Aidid, and M. Nusrang, "Pengelompokan Kabupaten/Kota Provinsi Sulawesi Selatan dan Barat Berdasarkan Angka Partisipasi Pendidikan SMA/SMK/MA Menggunakan K-Medoid dan CLARA,” VARIANSI J. Stat. Its Appl. Teach. Res., vol. 1, no. 3, p. 48, 2019 , doi: 10.35580/variansiunm12899.

[8] R. Goejantoro, "Perbandingan Pengelompokan K-Means dan K-Medoids Pada Data Potensi Kebakaran Hutan/Lahan Berdasarkan Persebaran Titik Panas (Studi Kasus : Data Titik Panas Di Indonesia Pada 28 April 2018) Comparison," vol. 10, no. April 2018, pp. 143-152, 2019.

[9] S. Nirmal, "Comparative study between k-means and k-medoids clustering algorithms," Int. Res. J. Eng. Technol., vol. 839, pp. 839-844, 2019, [Online]. Available: https://www.irjet.net/archives/V6/i3/IRJET-V6I3154.pdf.

[10] D. Marlina, N. Lina, A. Fernando, and A. Ramadhan, "Implementasi Algoritma K-Medoids 


\section{KILAT}

Vol. 10, No. 1, April 2021, P-ISSN 2089-1245, E-ISSN 2655-4925

DOI: https://doi.org/10.33322/kilat.v10i1.1174

dan K-Means untuk Pengelompokkan Wilayah Sebaran Cacat pada Anak," J. CoreIT J. Has. Penelit. Ilmu Komput. dan Teknol. Inf., vol. 4, no. 2, p. 64, 2018, doi: 10.24014/coreit.v4i2.4498.

[11] F. Nhita, "Comparative Study between Parallel K-Means and Parallel K-Medoids with Message Passing Interface (MPI)," Int. J. Inf. Commun. Technol., vol. 2, no. 2, p. 27, 2017, doi: 10.21108/ijoict.2016.22.86.

[12] P. Surya and I. Laurence Aroquiaraj, "Performance Analysis of K-Means and K-Medoid Clustering Algorithms Using Agriculture Dataset," J. Emerg. Technol. Innov. Res., vol. 6, no. 1, pp. 539-545, 2019.

[13] N. Lestari Anggreini and S. Tresnawati, "Komparasi Algoritma K-Means dan K-Medoids Untuk Menangani Strategi Promosi di Politeknik TEDC Bandung," TEDC, vol. 14, no. 2, pp. 120-126, 2020.

[14] I. Algoritma and K. D. A. N. K. Dalam, "Implementasi algoritma k-means dan k-medoids dalam pengelompokan nilai ujian nasional tingkat smk," no. Ciastech, pp. 717-726, 2020.

[15] S. A. Abbas, A. Aslam, A. U. Rehman, W. A. Abbasi, S. Arif, and S. Z. H. Kazmi, "KMeans and K-Medoids: Cluster Analysis on Birth Data Collected in City Muzaffarabad, Kashmir," IEEE Access, vol. 8, pp. 151847-151855, 2020, doi: 10.1109/ACCESS.2020.3014021.

[16] M. Fuady and J. Nugraha, "IMPLEMENTASI METODE K-MEANS DAN K-MEDOIDS UNTUK Jurusan Statistika , FMIPA, Universitas Islam Indonesia Isnafuady1@gmail.com ABSTRAK PENDAHULUAN Inflasi merupakan permasalahan yang selalu dan pasti dialami oleh setiap negara . Disebabkan oleh pengaruh in,” pp. 327-337, 2017.

[17] Nurhayati, N. S. Sinatrya, L. K. Wardhani, and Busman, "Analysis of K-Means and KMedoids's Performance Using Big Data Technology," 2018 6th Int. Conf. Cyber IT Serv. Manag. CITSM 2018, no. Citsm, pp. 1-5, 2019, doi: 10.1109/CITSM.2018.8674251.

[18] I. Kamila, U. Khairunnisa, and M. Mustakim, "Perbandingan Algoritma K-Means dan KMedoids untuk Pengelompokan Data Transaksi Bongkar Muat di Provinsi Riau," J. Ilm. Rekayasa dan Manaj. Sist. Inf., vol. 5, no. 1, p. 119, 2019, doi: 10.24014/rmsi.v5i1.7381.

[19] A. Dharmarajan and T. Velmurugan, "Efficiency of k-Means and k-Medoids Clustering Algorithms using Lung Cancer Dataset," Int. J. Data Min. Tech. Appl., vol. 5, no. 2, pp. 150-156, 2016, doi: 10.20894/ijdmta.102.005.002.011.

[20] R. D. Ramadhani and D. J. Ak, "Evaluasi K-Means dan K-Medoids pada Dataset Kecil," Semin. Nas. Inform. dan Apl., no. September, pp. 20-24, 2017. 